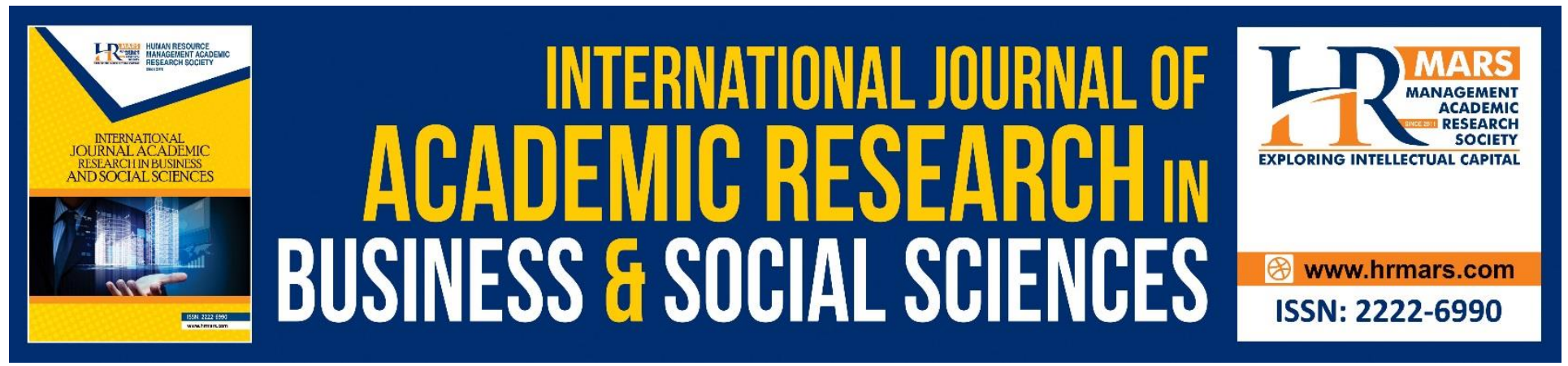

\title{
The Implementation of Tarbiyyah Program based on the Hostel Student Development Module (MPMA): A Study at the Religious Secondary Schools (SMKA) in Penang
}

Mohd. Suhardi bin Mat Jusoh, Shaik Abdullah bin Hassan Mydin, Jasni bin Sulong

To Link this Article: http://dx.doi.org/10.6007/IJARBSS/v8-i8/4475

DOI: $\quad 10.6007 /$ IJARBSS/v8-i8/4475

Received: 10 July 2018, Revised: 27 July 2018, Accepted: 21 August 2018

Published Online: 29 August 2018

In-Text Citation: (Jusoh, Mydin, \& Sulong, 2018)

To Cite this Article: Jusoh, M. S. bin M., Mydin, S. A. bin H., \& Sulong, J. bin. (2018). The Implementation of Tarbiyyah Program based on the Hostel Student Development Module (MPMA): A Study at the Religious Secondary Schools (SMKA) in Penang. International Journal of Academic Research in Business and Social Sciences, 8(8), 375-385.

Copyright: (C) 2018 The Author(s)

Published by Human Resource Management Academic Research Society (www.hrmars.com)

This article is published under the Creative Commons Attribution (CC BY 4.0) license. Anyone may reproduce, distribute, translate and create derivative works of this article (for both commercial and non-commercial purposes), subject to full attribution to the original publication and authors. The full terms of this license may be seen at: http://creativecommons.org/licences/by/4.0/legalcode

Vol. 8, No. 8, August 2018, Pg. 375 - 385 


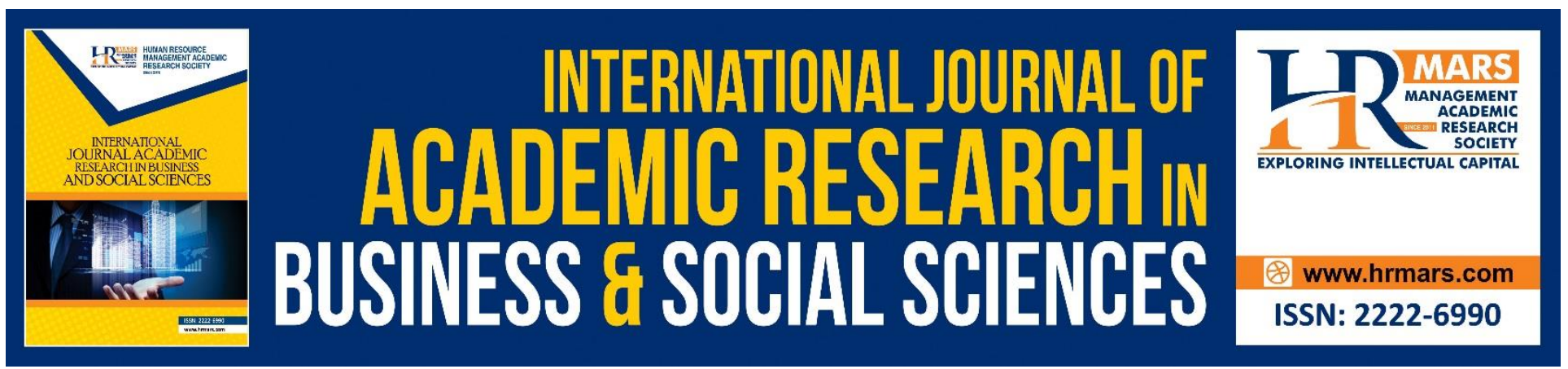

\title{
The Implementation of Tarbiyyah Program based on the Hostel Student Development Module (MPMA): A Study at the Religious Secondary Schools (SMKA) in Penang
}

\author{
Mohd. Suhardi bin Mat Jusoh, PhD \\ Centre for Modern languages \& Human Science, Universiti Malaysia Pahang \\ Email: suhardi@ump.edu.my
}

Shaik Abdullah bin Hassan Mydin, PhD

School of Distant Learning, Universiti Sains Malaysia

Email:abdullah@usm.my

Jasni bin Sulong, $\mathrm{PhD}$

School of Humanities, Universiti Sains Malaysia

Email: jasni@usm.my

\begin{abstract}
Tarbiyyah or education is an utmost tool to nurture our youth's personality nowadays amidst of global threats and challenges in the non-boundary world today. Thus, this research discusses the implementation of tarbiyyah programme in order to develop student's personality at the hostels of religious secondary schools in Penang based on the Hostel Student Development Module (MPMA) issued by the Ministry of Education Malaysia. The main objective of this study is to examine the implementation of tarbiyyah programme based on the elements of rūhiyyah (spiritual) and 'aqliyyah (intellectual) for student's personality development in religious secondary schools, as well as to evaluate the effectiveness of programme implementation in the aspects of shaping student's personality. Finally, to propose some improvements as a personality development module in the term of spiritual and intellectual achievement. This research employs qualitative methods whereby data was collected through observations and interviews. In general, the findings of qualitative research showed that the implementation of tarbiyyah programme can improve student self-esteem, especially in the aspects of spiritual and intellectual intelligence. Thus, this study concludes that the implementation of tarbiyyah programme based on the Hostel Student Development Module (MPMA) is very relevant and appropriate to be implemented at educational institutions as a personality development module.
\end{abstract}


INTERNATIONAL JOURNAL OF ACADEMIC RESEARCH IN BUSINESS AND SOCIAL SCIENCES

Vol. 8, No. 8, August 2018, E-ISSN: 2222-6990 C 2018 HRMARS

Keywords: Tarbiah Programme, Spiritual And Intellectual Development.

\section{Introduction}

Basically, the main objective in the implementation of tarbiyyah program in religious secondary schools (SMKA) is to develop for great personality, reliance and taqwa among the religious school students (Ministry of Education, 1997). These programs are also part of an Islamic educational program in the form of non-formal activities to complement formal Islamic education programs, in terms of reciprocity and complementary relationships (Hassan et al., 1981). In this regard, the Ministry of Education (1980) has stated that all activities during the hostel's leisure time are considered as additional or complementary activities to the existing programme.

Therefore, the implementation of tarbiyyah programs in the framework of non-formal activities can complement the formal Islamic learning objectives in the aspect of personality development and character building. As a learning process, the non-formal educational activities will influence students in their daily performance, besides influences from their sorroundings (Rogers, 2004). While the practice of formal education have some deficiency of effectiveness in the context of building human character as it was more towards academic excellence rather than values, morals and personalities advancement (Ibrahim, 1987).

Therefore, the significance role of tarbiyyah program is undeniable in terms of developing students' personality. In a meantime, the program can fulfill the aspirations of national education as intended in the National Education Philosophy. In this regard, the Hostel Student Development Module (MPMA) that was highlighted by the Ministry of Education (2007) is one of the frameworks and modules that can produce hostel students' who are well-respected and have endurance, faith and piety. Through this module, the development of students' personality is focused on the aspect of spiritual development (rühiyyah) as well as their intellectual ('aqliyyah) in an integrated way through the implementation of the following programs;

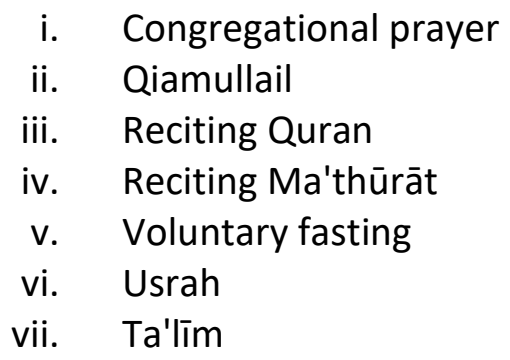

In the context of Islamic education, the above-mentioned programs are learning mechanisms for ruhiyyah and 'aqliyyah that can realize the aim for building students' personality. Thus, the goal could be achieved if the program that were highlighted are in line with the needs of students' physical and spiritual (Stapa, 1995). In Islamic devotion, every appreciation will refer to the heart and if that worship is performed perfectly, then it will transform into heart and soul that will create calmness. As a results, people will behave in good manners to Allah SWT as well as to human beings (Masyuri, 2012).

\section{Problem Statements}

The early findings of observation studies (2015) show that there are lack of appreciation in worship rituals if measured through elements of spiritual development (tarbiyyah rūhiyyah) such as mujāhadah al-nafs and al-ihsān among the hostel students' in Penang SMKA. The fact shows that most of the hostel students' were not consistent (istiqāmah) in the fulfillment of some obligatory 
INTERNATIONAL JOURNAL OF ACADEMIC RESEARCH IN BUSINESS AND SOCIAL SCIENCES Vol. 8, No. 8, August 2018, E-ISSN: 2222-6990 @ 2018 HRMARS

devotion, especially in performing fajr prayer in congregation on weekends. They failed to resist the inner temptation to enjoy long sleep on the break. Similarly, the practice of voluntary worship such as qiamullail, reciting Quran and Ma'thurāt as well as sunnah fasting. All those kind of devotion still need to be improved as a spiritual educational mechanism to oneself (Hawwa, 2005). In particular, the basis of these issues is related on the following factors;

Firstly, the absence of trainer who can actually carry out tasks as murabbi and mursyid in the context of guiding and mobilizing students' spiritual development and educational programs within the framework of the non-formal Islamic education program at the religious schools' hostel. According to Al-Mu'ayatah (2002), among the principal roles of murabbī is to perform the tasks of altazkiyah, namely cleansing and nurturing the human soul in accordance with the God aim as well as preserving them from the elements of evil and immoral. In this regard, the guidelines issued by the Ministry of Education (2007) have clearly stated, that is:

"Every warden is responsible for monitoring and taking notes on daily and periodic activities such as the prayer time and religious classes that are organized in the hostel."

Secondly, the 'aqliyyah teaching program that was implemented through mechanism of usrah and ta'lim seems to be unbalanced in the context of producing good personality, who practicing their faith prudently as well as getting an outstanding result in the examination. The progress of student performance seem to be inconsistent (istiqamah) with the training and guidance that are provided in the hostel of the religious secondary schools. The focus of performance should be in line with the statement of the Ministry of Education of Malaysia (1997);

"To achieve the perfect level of worship, the work performed must be based on the beliefs of knowledge and not by imitating".

Therefore, every hostel student in the context of tarbiyyah program should be given a good understanding towards the wisdom of knowledge to enhance quality of worship and character building. The improvement of worship as well as academic excellence is part of educational goals that every student needs to achieve (Mamat \& Wan Abdullah, 2010). At the same time, it is in line with the objective of students' personality development of SMKA's educational goals, that is:

"Produce individuals who are knowledgeable, strong believers, highly skilled, eminently superior, competent and possessing leadership qualities that fit the Islamic personality to fulfill the demand of this world and hereafter".

Therefore, based on the above problems statement, this research is at aim to analyze and improve the application of tarbiyyah program that based on the Hostel Student Development Module (MPMA). As the more civilize of humanity is the more complex of problems and necessities of human life (Masyuri, 2012), this research is indespensible to see the appreciation of hostels' student of religious secondary school in the tarbiyyah program. 
INTERNATIONAL JOURNAL OF ACADEMIC RESEARCH IN BUSINESS AND SOCIAL SCIENCES

Vol. 8, No. 8, August 2018, E-ISSN: 2222-6990 @ 2018 HRMARS

\section{Research Objective}

Specifically, the research objectives of the study is as follows:

1. To examine methods of implementation of tarbiyyah programs based on the elements of rūhiyyah and 'aqliyyah learning at the hostel of Penang SMKA.

2. To evaluate an effectiveness of the implementation of tarbiyyah program based on the Hostel Student Development Module (MPMA) of the Ministry of Education Malaysia (KPM).

3. To suggest some aspects of improvement together with self-development module for the SMKA hostel students'.

\section{Research Methodology}

This study is an exploratory research that has been developed through qualitative research. The data collection has been carried out through the method of observation and interview. To be clearer, the process of collecting data is explained as follows;

\section{Observation Method}

Observation is is a type of correlational research in which a researcher observes ongoing behavior. The method involves a direct observation of phenomena in their natural setting by carefully watching on someone or something. During collecting the data, researcher used direct recording mechanism in explaining behaviours (Lebar, 2009) from four sample of Penang SMKA. In this study, the researcher become participant by joining in and becomes part of the group of the study to get a deeper insight into their lives as well as by adapting oneself to the research environment. Before that, a structured surveillance was carried out by identifying items that need to be observed before an actual observation is taken place. A list of identified variables has been determined before the observation data been recorded, which has been accumulated from research problems. During the process of observation, the data has been recorded in descriptive form about activities of respondents as well as their behavior. The explanation notes will facilitated researcher to describe phenomenon and situation. In sum, some of the key points that researcher has taken note in the observation are as follows:

i. Time period, that is duration of the observation taken place.

ii. Constant records, where researcher records everything during the observation.

iii. Time sampling, observations are recorded at certain times on certain activities.

\section{Interview}

Interviews can be defined as a qualitative research technique which involves intensive individual conversations between researcher and respondents to explore their perspectives on a particular idea, program or situation. There are three fundamental types of research interviews: structured, semistructured and unstructured. But in this study, semi-structured interviews were carried out by having some principal question pertaining to the subject matter of the research. Specifically, the findings from interview is used to support arguments which can assist in elaborating research phenomenon with extra idea and sound wise (Marican, 2009). To fulfill the objective, form of interview is set up in conformity with the study objective as well as the study has arranged an appropriate interview questions that is in line with the research questions. In this case, the study has selected 15 respondents based on purposive sampling where face-to-face interview has been done with each 
INTERNATIONAL JOURNAL OF ACADEMIC RESEARCH IN BUSINESS AND SOCIAL SCIENCES

Vol. 8, No. 8, August 2018, E-ISSN: 2222-6990 @ 2018 HRMARS

respondent on convenient dates and times. Every answer by respondents have been recorded in written and audio mode, which is gradually transcribed by researcher. In order to ensure the smooth flow of interview process, the interview question is underlined based on structured interviews, with

little extension during the question.

\section{Research Findings and Analysis}

Finding analysis of the study has been processed from the above data collected. In the analysis, the synthesis of the data also involves a process of elaborating research problems based on research questions with the purpose of explaining the stated objectives (Awang, 2009). Accordingly, the findings of this study can be explained as follows;

\section{1) The practice of performing fajr prayer in congregation}

The findings of observation studies show that the practice of performing fajr prayer in congregation is fully implemented among boarding students in Penang SMKA. In fact, hostel students' are compulsory to realize the chore. This finding is based on student movement to the surau (prayer hall) during fajr and performing the prayer and the before sunnah as well. These findings show that the aspect of rūhiyyah elements by fighting against sleeping time and realizing of self strength (mujāhadah al-nafs) and do good (al-ihsān) by complying with the rules can be perceived on a small proportion of respondents who present for routine fajr prayer. The inference can be scrutinized based on the following observation data (2016);

\section{SCHOOL D : SS (5)}

Fajr time is 5.49 am. Students begin to move at 5.55 am. There are about 1 to 6 students in the surau. They call for prayers (azan) at about 5.58am. There are 8 male students and 2 female students who performing sunnah before prayer. The number of male students are more than female before the prayer begin. It was found that there was no warden on duty during fajr prayer congregation.

The above observation findings are parallel with the respondents response from interviewing data ( 2016) as follows;

Respondent 11 (GL 11) :

"If the fajr prayer ... is about a row or a row and half, during fajr prayers and that's all. But for Zuhr, 'Asar, Maghrib and Isya' prayers, there are alhamdulillah."

\section{The practice of Qiamullail}

Qiamulail means spending the night, or part of it, by doing worship such as prayer, reading Quran and remembering Allah (zikr). The findings of observation studies show that the practice of qiamullail is implemented consistently (istiqamah) among a small group of hostel student at the Penang SMKA. Thus, the concept of mujāhadah al-nafs and al-ihsan only perceived by a small number of respondents. Even though the program is voluntary, it needs to be accompanied by many students. In conclusion, the program need involvement of instructor (murabbi) who will look after spiritual guidance for hostel students'. Among the observation data (2016) that explained this findings are as follows; 
INTERNATIONAL JOURNAL OF ACADEMIC RESEARCH IN BUSINESS AND SOCIAL SCIENCES

Vol. 8, No. 8, August 2018, E-ISSN: 2222-6990 @ 2018 HRMARS

SCHOOL C : PQ (1)

During Qiamullail, form 1 and 2 are the most whom attended. Forms 3, 4, 5 and 6 are just a few of them. Start with 2 rakaats of tahajjud prayers and ended with 3 rakaats of witir prayers. Only $1 \frac{1}{2}$ rows of students are present.

\section{SCHOOL B : PQ (1)}

Only students involved. No warden has been seen. At 4.30 am the bell is rang. Student movements do not happen simultaneously. Students are preparing to perform qiamullail at $5.00 \mathrm{am}$. Students execute qiamullail by performing 2 rakaats of tahajjud prayer. Then students perform the hajat prayer. Students recite doa. Students ended the qiamullail by performing witr prayer. The implementation of qiamullail shows that students was enthusiastic and excited. The observation ended at $5.45 \mathrm{am}$.

The above observation findings are parallel to the findings of the data interviews (2016), as follows;

Respondent 12 (GL 12):

"From what I have noticed ... the number of students in the form 2 is around 41 students, but those who are involved in the program are only $40 \%$ to $50 \%$, and those who are not present are at the hostel".

3. The practice of reciting Quran (Tadarus).

Observation findings show that the practice of reciting Quran is implemented among respondents on three main intervals, that is after the Asr, Maghrib and Isya' prayers. However, the elements of rūhiyyah learning in understanding the meaning of Qur'anic verses seem has not been practiced among respondents, as they are merely reading the verses to complete the task. This finding is based on the following observation data (2016);

SCHOOL A : TQ (1):

"All students stay in the surau after performing the Isya's prayer. At 10.35 pm, all students began to recite Quran and many are cooperating. Form 5 student has led the reading (tadarus). The surah that is read is al-Mulk. In a meantime, several students performing Isya prayers while most of them reciting the Quran. Neither warden nor student who gave an instruction. All students return to their dorm at $10.45 \mathrm{pm}$.

SCHOOL C : TQ (1):

"There is a warden who monitor the tadarus program. It is conducted after the Maghrib prayer. Students recite and memorize 3 sentences or more individually. Students recite surah al-Naba'. The students disperse and move towards study room".

The observation findings as mentioned above are in line with the respondents' responses through interviews data ( 2016) as follows:

Respondent 9 (ML9) : 
INTERNATIONAL JOURNAL OF ACADEMIC RESEARCH IN BUSINESS AND SOCIAL SCIENCES

Vol. 8, No. 8, August 2018, E-ISSN: 2222-6990 @ 2018 HRMARS

"So far, SMKA hostel students' are still lack of knowledge because there is no guidance ... there is no instructor to guide them in understanding one verse to another."

4. The practice of reciting $M a^{\prime}$ thūrāt.

Ma'thürāt is a set of dhikr and prayer that is taken from the Prophet (pbuh). The findings of observation studies show that Ma'thūrāt's dhikr is practiced by the entire hostel students' at three different times, after fajr prayers, 'asr and before maghrib prayers. This finding is based on the following observation data (2016);

SCHOOL A : BM (1):

Ma'thürät's recitation is conducted by a senior of form 5 student who is the imam of fajr prayers. Ma'thūrāt is reciting in congregation. Some students recite Ma'thūrāt based on the text while others did not. Ma'thūrāt ends with a prayer recitation at 6.30am.

SCHOOL B : BM (4):

(Around $6.15 \mathrm{pm}$ ) .. bell is rang and students get down. Students are free to wear any clothes. Ma'thūrāt recitation is led by a form 5 student. Students sit randomly in the hall. Each students has a Ma'thūrāt handy book. Students only recite the short Ma'thūrāt (brief). There are students who came late. Ma'thūrāt recitation ends at 6.35 pm, closing ritual and students enjoy their dinner.

5. The practice of voluntary fasting.

The voluntary fasting is a fast that is performed on monday and khamis, not in the month of Ramadan. The observation studies show that the practice of voluntary fasting is conducted routinely in a small number of boarding students in Penang SMKA. In this case, the objective on coaching hostel students' in the context of self-control and resilience to any negative influences as a rūhiyyah development element seems to be achieved on some group of respondents only who always performing voluntary fasting. This finding is based on the following observation data (2016);

SCHOOL A : PS (1):

The number of students who performs voluntary fasting is about 1 to 21 people. The majority of them are form 6 and 5. There are also students of form 1, 2, 3 and 4 who join the program.

\section{SCHOOL D : PS (1):}

There are 10 of form 5 students who perform voluntary fasting. While students of form 1, 2 and 3 who follow the program were around 19 people. The total estimation who perform voluntary fasting is 42 students.

The observation findings that are mentioned above is supported by the following data interviews (2016); 
INTERNATIONAL JOURNAL OF ACADEMIC RESEARCH IN BUSINESS AND SOCIAL SCIENCES

Vol. 8, No. 8, August 2018, E-ISSN: 2222-6990 C 2018 HRMARS

Respondent 14 (GP 14):

"On what I have seen, it does not work on a large number of students but only on several of them who is able to perform voluntary fasting on Monday and Thursday continuously."

6 ) The usrah and ta'limm program.

Usrah is a group of Muslim individuals who sitting together by discussing and helping out one another towards a better understanding of Islam. Meanwhile ta'lim is an Arabic term that referring to teaching or coaching, which is arranged in explaining the beauty of Islam. The findings from the observation study show that the usrah and ta'lim have been implemented among all boarding students in Penang SMKA as a medium of their mental (aqliyyah) learning program. In this regard, the implementation of the programs are basically fulfilled one of the objectives in nurturing awareness of self-realization to achieve excellence in this world and hereafter. This finding is based on the following observation data (2016);

SCHOOL C : PU (1):

Usrah is spontaneously organised. The subject that was discussed is "The Islamic environment, reality or fantasy in Irshad". The subject is determined by the head of Da'wah Bureau. Each group looks energetic. There was a question and answer between naqib and members of the usrah group. The number of usrah members consist of 7 and above.

SCHOOL C : PU (2):

Observation starts at $8.15 \mathrm{pm}$, a student gives an instruction to run usrah. Usrah members assemble randomly, as well as in selecting the naqib. Subjects are given spontaneously that related with Islamic education (tarbiyah).

SCHOOL B : PI (5):

Tazkirah (short advices) begins at 8.06 pm, students are reciting al-Fatihah. Students assembling in the halaqah (cirle). A student delivers tazkirah. The topic is "demonic channels that entering the human body." The presenter is found to be a capable student as he presents the topic very well. He presented the tazkirah according to the text. Students have responded positively, by answering all of questions that were asked by the presenter.

\section{SCHOOL C : PI (2):}

The program begins at $7.50 \mathrm{pm}$. It is run by a religious teacher (from the same school). Students are referring to a specific book. The subject is "the Forty Hadith". The teacher give an instruction to silent. Students get along with the instructions. Students look focus. However, there are some students who do not pay attention since they are sitting a bit far from the teacher.

\section{Discussions and Conclusion}

The findings of the study show that the implementation of tarbiyah programs among hostel students' at Penang SMKA is parallel to the goal of the Hostel Development Module (MPMA), which is to 
INTERNATIONAL JOURNAL OF ACADEMIC RESEARCH IN BUSINESS AND SOCIAL SCIENCES

Vol. 8, No. 8, August 2018, E-ISSN: 2222-6990 @ 2018 HRMARS

enhance the personality of students. In the implementation of fajr prayer, the overall findings showed that the underlined module has been achieved succesfully, when it is found that some respondents seem to be consistent in performing fajr prayer in congregation at the hostel. The findings have illustrated that the application of rūhiyyah learning elements such as mujāhadah al-nafs and ihsān have been realized among hostel students' and this will help them in building their good character in the future.

In the aspect of qiamullail program, the overall findings show that the objective in disciplining students by training them to perform night prayer is effectively achieved though on a small number of students. These findings are in line with previous studies that portray a consistent practiced of religious rituals will prevent them from risky behaviors (Abu Bakar, 2011). Furthermore, in the context of reciting Quran and Ma'thūrāt, the overall findings show that both activities are consistently practiced by most of the hostel students' and this finding is also in line with the previous study (Ismail, 2012) which can improve their disciplinary issues. While on the practice of voluntary fasting, the finding of the study shows that the objective to produce students who can avoid immorality and perceived patience in the context of rühiyyah learning is also achieved on a small number of the respondents. The programs managed to shape their inner nature to be more obedient and respectful to the teachings of Islam.

In the context of 'aqliyyah teaching, the overall study found that the implementation of usrah and ta'lim programs are productively realized towards knowledgeable hostel students' by having a continuous learning and thinking circle-group during their leisure time. In this case, the findings are also in line with the previous study's recommendation that the learning circle-group should be held daily, especially after maghrib or fajr prayers, to give a deep and continous guidance in Islamic personality. The discussion which carry various of activities is fruitfull to complement any deficient understanding in their formal-learning program (Esa, 2004).

As a conclusion, the implementation of tarbiyah program as a non-formal Islamic education program among hostel students' in Penang SMKA is in line with the objective of building students's personality as required by the Ministry of Education Malaysia (KPM) in the Hostel Student Development Module (MPMA). However, this study suggests that some aspects of improvement need to be enhanced, especially in terms of organizational and methodology so that the impact will reflect to all students. Thus, the study concludes that the implementation of those program that based on the Hostel Development Module (MPMA) are very suitable to be applied in other SMKAs as well as in any educational institution in this country. It is appropriate to be a module for developing and strengthening students' self-esteem as well as building their personality beyond the framework of formal education.

\section{Correspondence Author}

Jasni Sulong

School of Humanities, Universiti Sains Malaysia, 11800 Pulau Pinang, Malaysia

Email: jasni@usm.com 
INTERNATIONAL JOURNAL OF ACADEMIC RESEARCH IN BUSINESS AND SOCIAL SCIENCES

Vol. 8, No. 8, August 2018, E-ISSN: 2222-6990 @ 2018 HRMARS

\section{Acknowledgement}

This study was part of PhD's finding that was done by Mohd Suhardi bin Mat Jusoh, entitled "Pelaksanaan Program Tarbiah dalam Kalangan Pelajar Asrama Sekolah Menengah Kebangsaan Agama (SMKA) Pulau Pinang" at Universiti Sains Malaysia, Penang (2015).

\section{References}

Abu Bakar, A. (2011). Pembinaan Model Kesejahteraan Diri Remaja di Terengganu. Universiti Malaya: Thesis Doctor of Philosophy at the Faculty of Education.

Al-Mu'ayatah, A. A. (2002). al-Madkhal ilā Usūl al-Tarbiyah al-Islāmiyyah. Qāhirah: Dār al-Tawzī' wa al-Nasyr al-Islāmiyyah.

Awang, I. (2009). Penyelidikan Ilmiah, Amalan Dalam Pengajian Islam. Shah Alam: Kamil \& Syakir Sdn. Bhd.

Department of Islamic Studies and Moral, Ministry of Education Malaysia (1997). Program Kecemerlangan Sekolah Menengah Agama (Iklim ) Sekolah. Kuala Lumpur : Kementerian Pendidikan Malaysia.

Department of Islamic Studies and Moral, Ministry of Education Malaysia (1997). Program Kecemerlangan Sekolah Menengah Kebangsaan Agama (sahsiah). Kuala Lumpur: Jabatan Pendidikan Islam dan Moral.

Esa, M. (2004). Pendidikan Islam Dalam Program Pusat Pemulihan Akhlak Wanita ; Kajian Kes di Taman Seri Puteh, Cheras Selangor. Universiti Kebangsaan Malaysia: Master dissertation at Faculty of Islamic Studies.

Hassan, M. K. et.al. (1981). Pendidikan Koleksi Dakwah Islamiah Malaysia. Kuala Lumpur: Yayasan Dakwah .

Hawwa, S. (2005). al-Mustakhlis Fī Tazkiyah al-Nafs. Qāhirah: Dār al-Salām.

Ibrahim, A. (1987). Pendidikan Islam di Sekolah perlu diorientasikan Kepada Penghayatan dan Amalan. Jurnal Pendidikan Islam, 1(2), 1-10.

Ismail, I. (2012). Budaya Nilai-nilai Keagamaan dan Disiplin Pelajar di Sekolah Menengah Agama Negeri Selangor Darul Ehsan. Universiti Kebangsaan Malaysia: Thesis Doctor of Philosophy at the Faculty of Education.

Konting, M. M. (1990). Kaedah Penyelidikan Pendidikan. Kuala Lumpur: Dewan Bahasa dan Pustaka. Lebar, O. (2009). Penyelidikan Kualitatif, Pengenalan Kepada Teori dan Metod. Tanjong Malim: Universiti Pendidikan Sultan Idris.

Mamat, M. A., Wan Abdullah, W. S. (2010). Tujuan Pendidikan dan Kaedah Pengajaran Abu Hanifah dalam Kitab al-Alim wa al-Muta'allim. Jurnal Akidah dan Pemikiran Islam. 11(1), 129-166.

Marican, S. (2009). Penyelidikan Sains Sosial . Batu Caves: Edusystem.

Masyuri, M. (2012). Prinsip- Prinsip Tazkiyah al-Nafs dalam Islam dan Hubungannya dengan Kesihatan Mental. Jurnal Pemikiran Islam. 37(2), 95-102.

Ministry of Education Malaysia (1980). Buku Panduan Untuk Guru Asrama. Kuala Lumpur : Bahagian Sekolah - Sekolah, Kementerian Pelajaran Malaysia.

Ministry of Education Malaysia (2007). Modul Pembangunan Murid Asrama (MPMA). Putrajaya: Bahagian Sekolah Kementerian Pelajaran Malaysia.

Rogers, A. (2004). Non-Formal Education- Flexible School or Participatory. Hong Kong: The University of Hong Kong.

Stapa, Z. (1995). Akhlak \& Tasawuf Islam. Kuala Lumpur : Berita Publishing Sdn. Bhd. 